\title{
Problems of Sustainable Use and Management of Water and Land Resources in Uzbekistan
}

\author{
Rashid Kulmatov \\ Department of Applied Ecology, National University of Uzbekistan, Tashkent, Uzbekistan \\ Email: rashidkulmatov@yahoo.com
}

Received October 7, 2013; revised November 9, 2013; accepted December 5, 2013

Copyright (c) 2014 Rashid Kulmatov. This is an open access article distributed under the Creative Commons Attribution License, which permits unrestricted use, distribution, and reproduction in any medium, provided the original work is properly cited. In accordance of the Creative Commons Attribution License all Copyrights (C) 2014 are reserved for SCIRP and the owner of the intellectual property Rashid Kulmatov. All Copyright (c) 2014 are guarded by law and by SCIRP as a guardian.

\begin{abstract}
In this paper, the problems of rational use, protection and management of water and irrigated land resources of Uzbekistan are discussed. Uzbekistan is using more than $\mathbf{5 0 \%}$ water resources of the region and therefore it's more vulnerable to the problems of water deficiency and pollution caused by mismanagement, use of outdated technologies, and climate change impact. Utilization of water resources on main branches of economy (irrigation, industry and drinking water supply) from 2000-2009 and in some cases beyond this period was analyzed. Based on the data analyzed, the conditions of irrigated land degradation in Uzbekistan are estimated. The results of this analysis suggest several possibilities toward a sustainable use of irrigated lands: i) reduction of the groundwater table depth; ii) decrease of the level of mineralization of groundwater, and iii) improvement of ameliorative conditions of irrigated lands. The causes resulting in degradation of the irrigated lands and practical measures on the reduction of salinization of the irrigated lands are also recommended.
\end{abstract}

\section{KEYWORDS}

\section{Water Resources; Irrigated Lands; Salinization; Mineralization; Uzbekistan}

\section{Introduction}

The Aral Sea basin, including five Central Asian countries (Kazakhstan, Kyrgyzstan, Tajikistan, Turkmenistan, and Uzbekistan), is known to the world due to an extensive and irrational water and land development in the Soviet era, which causes a heavy degradation of water and land resources and the Aral Sea catastrophe [1,2]. The economic development of the Aral Sea basin (ASB) countries, particularly Uzbekistan in many respects, is connected to the availability of water and land resources and their rational use. Uzbekistan has the largest territory of irrigated agriculture in the region, and around 25\% $30 \%$ of Uzbekistan's GDP is derived from agriculture with about $45 \%$ of the population employed in the sector [2]. The irrigated area is $4.3 \mathrm{mln} \cdot$ ha (about $10 \%$ ), the rain fed area is 900,000 ha (1.7\%), pasture land is $22.4 \mathrm{mln} \cdot \mathrm{ha}$ (50.1\%), forest cover is $1.3 \mathrm{mln} \cdot \mathrm{ha}(3.2 \%)$, and the area that is not in use is $16 \mathrm{mln} \cdot \mathrm{ha}$ (35.3\%) [3]. Irrigated lands provide more than $95 \%$ of all agricultural production of country.
Irrigation systems are widely developed in Uzbekistan. The irrigation is of the surface flow type, including about $63.9 \%$ of furrow irrigation, $31.6 \%$ of strip and $4.5 \%$ of basin irrigation. Sprinklers are not used. Drip irrigation is on a stage of small pilot projects [4]. The methods which are being practiced lead to the loss of a great volume of water through evaporation and filtration $[4,5]$.

The irrigated lands are characterized by low level of fertility and low humus content, usually not more than $1 \%$ - $2 \%$ organic matter [2]. Cotton still remains one of the most important crops, although between 1990 and 2010 its share of irrigated agriculture decreases from $50 \%$ to $30 \%$ [3]. Wheat is also a dominant crop in the country, which covers about $30 \%$ of total irrigated area. Therefore, sustainable land use and management is essential for securing food production, especially in view of climate change, decreasing water resources and growing population, in the light of limited irrigated land [4,5].

During the Soviet era, huge and extensive irrigation networks and drainage canals were created. Pumping 
stations supplied water for irrigation of more than 2.2 $\mathrm{mln} \cdot \mathrm{ha}$ in the country. Some $136,000 \mathrm{~km}$ of the drainage networks including 29,000 km of main and inter-farm collector-drains and 107,700 km of on-farm drainage networks (including 39,200 km of subsurface drains) were built on the irrigated area of over $2.5 \mathrm{mln} \cdot \mathrm{ha}$. In Uzbekistan, the total length of inter-farm and on-farm irrigation networks amounts to $27.62 \mathrm{~km}$ and $167.38 \mathrm{~km}$, respectively [1,2]. The cotton-monoculture was the main reason for the ecological problems in Uzbekistan. Moreover, a variety of pesticides, herbicides, defoliants, and fertilizers have been heavily used in the cotton fields in order to increase yield productivity [1,2].

The policy issues of agricultural and rural development of Uzbekistan as well as the environmental and soil problems have been studied and described $[5,6]$. The authors highlighted a land degradation problems among Central Asian countries but did not provide a thorough explanation of effects, such as soil degradation (loss of fertility, salinization, water logging), degradation of pastures, degradation of forests, and erosion [7]. Most of the researches were made on the effects of agricultural activities on soil quality and other environmental factors focused mainly on the Aral Sea region [7]. In fact, explanation of soil degradation problems and their impacts on agricultural development within boundaries of each country will help to understand specific circumstances of soil degradation processes. The most serious environmental problems threatening the country's natural resources are incremental water deficiency and contamination, soil degradation, salinization, wind and water erosion, overgrazing, deforestation and loss of biodiversity, and the reduction of productivity of arable lands [4-7]. It is important to note that climate change is being observed in all Aral Sea basin countries, including the territory of Uzbekistan. Climate warming poses a great risk to the sustainable development in the fields of land-water resources, agriculture and food security [8].

The purpose of the present work is to explore the dynamics of utilization of water resources and condition of irrigated lands in Uzbekistan, mainly focusing on the period from 2000 to 2009.

\section{Materials and Methods}

The Republic of Uzbekistan covers 447,000 km² (44.7 $\mathrm{mln}$. ha) and is situated between the Amu Darya and Syr Darya rivers in Central Asia in the continental subtropics. The country's territory extends $1400 \mathrm{~km}$ from west to east, and $925 \mathrm{~km}$ from south to north (Figure 1).

Uzbekistan enjoys several advantages of favourable natural and geographic conditions as its territory includes a combination of mountainous, plain, and desert terrain. In the east and south-east, sandy steppes make way for

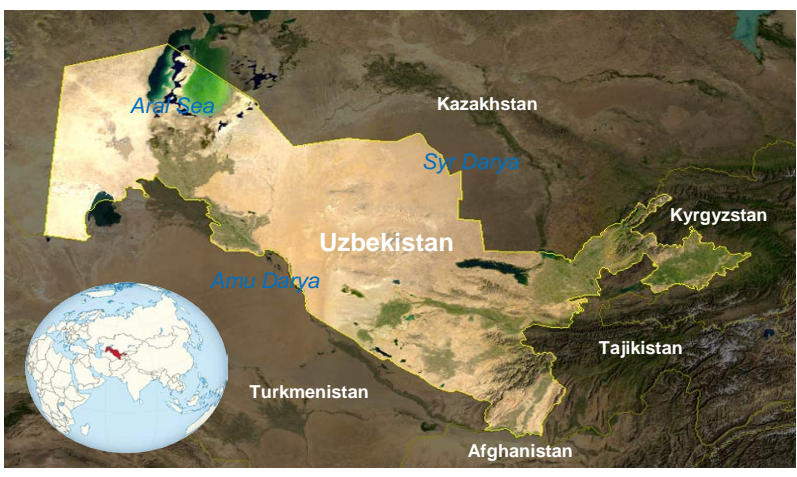

Figure 1. The map of Uzbekistan.

hills and piedmont areas [8]. Mountains constitute the largest ecosystem in the region and are highly significant for the country's environmental balance and sustainability. They are an important source of land, water, biodiversity, energy and mineral resources, and have a determining role in climate and landscape diversity. West Tien Shan and Gissar-Alay are the major mountain ranges of Uzbekistan. Uzbekistan's climate is subtropical, sharply continental, hot and dry, with marked differences in day time - night time and summer-winter temperatures. Its climatic features are due to a combination of three major factors: solar radiations, general atmospheric circulation and the local terrain [8]. Favourable climatic conditions, land and labour resources stipulated the development of cotton, rice, vegetable growing, gardening and vineyard which are characteristics of dry subtropical zone and require essential water consumption.

We analyzed the parameters of water utilization from surface reservoirs for irrigation and industrial needs mainly between 2000 and 2009. Data from 2000 to 2009 have also been used to determine the condition of irrigated lands in Uzbekistan $[9,10]$. In addition, where applicable, long-term data beyond 2000 and 2009 was processed, transformed and analyzed to explain the utilization of water resources and irrigated soil degradation processes in Uzbekistan.

\section{Results and Discussion}

\subsection{Problems of Water Resources Use and Management}

Uzbekistan is the major water consumer in the ASB. The total water use of the Amu Darya and Syr Darya rivers accounts for 52\% in Uzbekistan, $20 \%$ in Turkmenistan, $11 \%$ in Tajikistan, $7 \%$ in Kyrgyzstan and $10 \%$ in Kazakhstan [5]. More than $60 \%$ of return waters of the region is formed in the territory of Uzbekistan. About 6\% of the Amu Darya and 13\% of the Syr Darya rivers flows are formed in the territory of Uzbekistan. Water infrastructure of Uzbekistan consists of $180 \mathrm{~km}$ of canal networks, over 800 large waterworks and pumping stations, 
55 water reservoirs with total capacity of 19.8 billion $\mathrm{m}^{3}$ and more than 4100 wells. The main consumers of water resources in the country are: agriculture, industry and households $[2,4,5]$. The total amount of water consumed for households is equal to $6.4 \mathrm{mln} \cdot \mathrm{m}^{3}$ per day, $38 \%$ of which comes from surface and $62 \%$ from underground sources. Total annual volume of water required for economic - drinking purposes is $2.33 \mathrm{~km}^{3}$ (Figure 2).

The centralized water supply captures $89.4 \%$ of city and $73.1 \%$ of rural population of the country. The major consumers of surface water sources in the country are: irrigated cropland and industry (Figure 3). The greatest utilization of water from reservoirs for irrigation and industry was recorded in $2005\left(59476.4 \mathrm{mln} \cdot \mathrm{m}^{3}\right), 2006$ $\left(58716.7 \mathrm{mln} \cdot \mathrm{m}^{3}\right), 2004\left(58457.3 \mathrm{mln} \cdot \mathrm{m}^{3}\right)$, and in 2003 $\left(56499.6 \mathrm{mln} \cdot \mathrm{m}^{3}\right)$. The least volumes of water intake for the above-stated needs were recorded in 2008 (43869.8 $\left.\mathrm{mln} \cdot \mathrm{m}^{3}\right)$ and $2001\left(43869.8 \mathrm{mln} \cdot \mathrm{m}^{3}\right)$. The volume of water used for irrigation has increased from $38835.7 \mathrm{mln} \cdot \mathrm{m}^{3}$ in 2008 to $44718.4 \mathrm{mln} \cdot \mathrm{m}^{3}$ in 2009 (15.1\%). Out of total amount of water taken from reservoirs, share of irrigation was $92.82 \%$ in $2003,92.71 \%$ in 2001 , $88.52 \%$ in 2008 , $89.03 \%$ in 2009 , whereas the rest of water was used for household, energy industry needs (Figure 3).

The increase in the water use is partly connected to

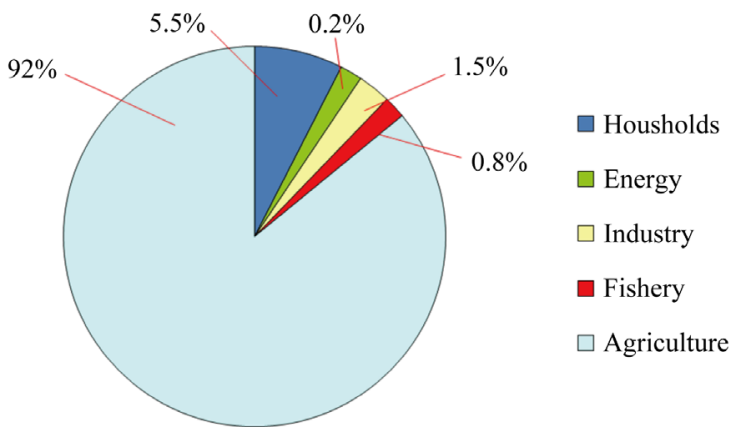

Figure 2. Average water use by sectors of economy in Uzbekistan 2000-2010.

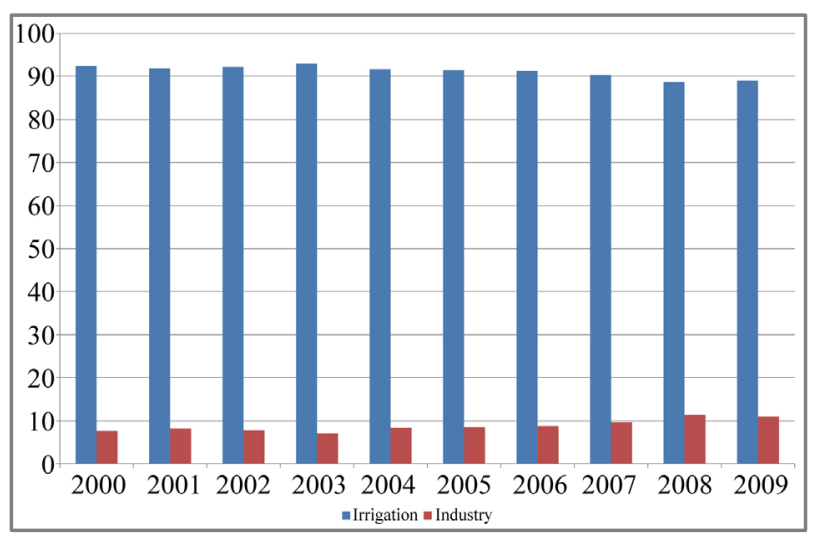

Figure 3. Utilization of water resources by irrigation and industry in Uzbekistan. industrial needs. Growth of volume of water use for industrial purposes begins after 2003. In 2003, the water used was $4054.0 \mathrm{mln} \cdot \mathrm{m}^{3}$ and $4865.0 \mathrm{mln} \cdot \mathrm{m}^{3}$ in 2004. Water use has increased by $811 \mathrm{mln} \cdot \mathrm{m}^{3}(20 \%)$. In 2009, in comparison with 2000, the volume of water used for industrial needs has increased by $1843.8 \mathrm{mln} \cdot \mathrm{m}^{3}$ (50.33\%). Annually, the total amount of water releases from surface reservoirs was between $43870.0 \mathrm{mln} \cdot \mathrm{m}^{3}$ up to 59476.0 $\mathrm{mln} \cdot \mathrm{m}^{3}$. Water use in irrigation was between 38835.0 $\mathrm{mln} \cdot \mathrm{m}^{3}$ and $54403.0 \mathrm{mln} \cdot \mathrm{m}^{3}$, whereas for industrial needs, it was between $3647.0 \mathrm{mln} \cdot \mathrm{m}^{3}$ and $5506.0 \mathrm{mln} \cdot \mathrm{m}^{3}$.

Water use per irrigated area has decreased over time from 1985 to 2010 (Figure 4). In 1985, use of water per irrigated hectare (ha) of irrigated area accounted for 22.4 $\mathrm{mln} \cdot \mathrm{m}^{3} / \mathrm{ha}$, and in 2005 , use of water per irrigated hectare of irrigated area accounted for $16.0 \mathrm{~m}^{3} / \mathrm{ha}$. Beyond the analyzed period, overall decrease in water use per hectare of irrigated land can be observed in a longer perspective.

In addition, there is a trend of decreasing water-intensive agricultural products. As presented in Figure 5, in the overall composition of agricultural products, the share of cotton decreased down to $30 \%$ by 2010 , while it used to cover half of the irrigated lands in 1990.

The situation with water supply in Uzbekistan might worsen due to the expected reduction of existing water resources with the most acute consequences occurring in the Aral Sea area. In whole, the volume of water used for

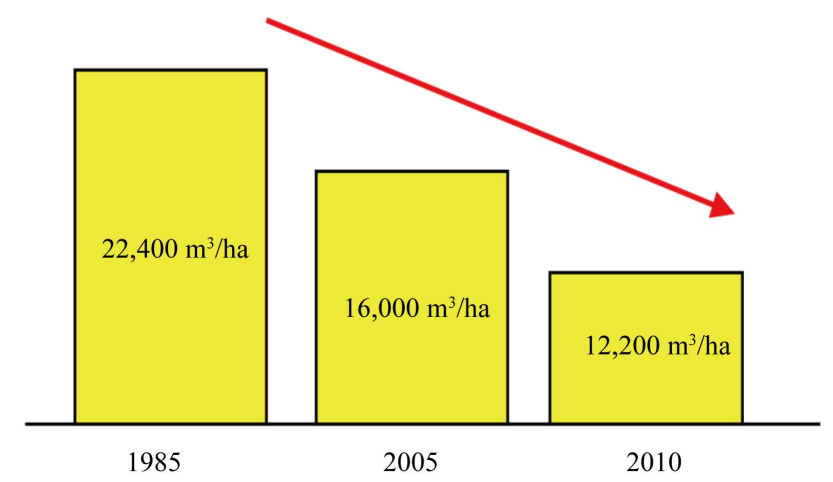

Figure 4. Decrease in marginal water use per irrigated hectare in Uzbekistan from 1985 to 2010.

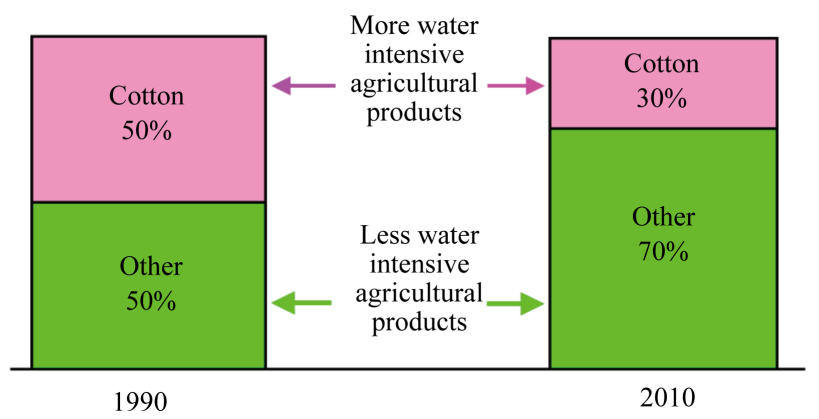

Figure 5. Production of agricultural products in Uzbekistan from 1990 to 2010. 
irrigation depends on type and the size of areas under crops, water content, a source of water, land salinization and groundwater table, an ameliorative condition of the irrigated lands, a management technique and other factors.

\subsection{Irrigated Land Problems}

On the basis of surface territory, Uzbekistan is divided into two unequal parts. About $78.7 \%$ of the territory of Uzbekistan is desert plains which are predominantly covered with brown meadow and grey-brownish desert soil and the remaining is high mountains ridges and intermountain valleys which comprise of sands and alkaline soils [2]. Soil cores, which is divided into 0 - 28, 28 - 49, 49 - 96, and 96 - 126 cm depths, were randomly collected from the irrigated fields in 2000-2009. Soil cores were pooled and mixed to obtain a composite sample for each depth. All the analysis was done by following standard procedures. Classification of V. Priklonskiy (1960) for the determination of the groundwater mineralization degree is used [11]. Data on the groundwater mineralization degree is given in Table 1.

The groundwater mineralization degree depends to a large extent on the human factor, of its methods of work in agriculture. Therefore, the groundwater mineralization degree has a tendency to increase or decrease the content of salts. Also, the classification of V. Priklonskiy [11] for the determination of the degree of irrigated land salinization is used (Table 2).

\subsection{Conditions of the Irrigated Lands for the Period from 2000 to 2009}

According data of the MAWR and the State Committee of "Uzergeodezkadastr”, irrigated lands currently occupy by 4313.9 th ha, which is about $10 \%$ of the total lands of the country. Between 2000 and 2009, the area of irrigated lands increased by 68.2 th·ha from 4245.7 to 4313.1 th·ha, and the increase was due to their conduct in circulation previously used virgin and fallow lands suitable for agriculture (Figure 6).

Studying groundwater table of the irrigated lands is important. In the majority of cases groundwater table defines productivity of agricultural crops, and also a possible degree salinization of the irrigated lands. It is known that the groundwater table in nature can exist only with the availability of the sources of their feeding. Intensive flood irrigation with poor drainage networks may have resulted in water logging and secondary salinization of irrigated lands.

\subsection{Depth of Groundwater Table}

The main source of feeding and cause nearly bedding groundwater level in irrigated agriculture are infiltration water from hydraulic and irrigation systems and irrigated fields as well as the refill reserves of their important role play and precipitation (rain and snow). One of the main

Table 1. Classification on the degree of groundwater mineralization (by B. Proklonskiy).

\begin{tabular}{ccc}
\hline No. & Category & Solid residue, $\mathbf{g} \mathbf{l}$ \\
\hline 1 & Fresh & $0-1$ \\
2 & Low-mineralized & $1-3$ \\
3 & Average-mineralized & $3-10$ \\
4 & Strong-mineralized & $10-50$ \\
5 & Salt & $>50$ \\
\hline
\end{tabular}

Table 2. Classification of land according to the salinization degree as a function of chemical composition, $\%$.

\begin{tabular}{|c|c|c|c|c|c|c|c|}
\hline \multirow{2}{*}{ No. } & \multirow{2}{*}{ Degree of salinization } & \multirow{2}{*}{$\begin{array}{c}\text { Sulfate } \\
\text { solid residue }\end{array}$} & \multicolumn{2}{|c|}{ Chloride-sulfate } & \multicolumn{2}{|c|}{ Sulfate-chloride } & \multirow{2}{*}{$\begin{array}{l}\text { Chloride } \\
\text { Chloride }\end{array}$} \\
\hline & & & solid residue & Chloride & solid residue & Chloride & \\
\hline 1 & Not saline & $<0.3$ & $<0.1$ & $<0.01$ & $<0.01$ & $<0.01$ & $<0.01$ \\
\hline 2 & Slightly saline & $0.3-1.0$ & $0.1-0.3$ & $0.01-0.05$ & $0.1-0.3$ & $0.01-0.04$ & $0.01-0.03$ \\
\hline 3 & Moderately saline & $1.0-2.0$ & $0.3-1.0$ & $0.05-0.2$ & $0.3-0.6$ & $0.04-0.2$ & $0.03-0.1$ \\
\hline 4 & Saline & $2.0-3.0$ & $1.0-2.0$ & $0.2-0.3$ & $0.6-1.0$ & $0.2-0.3$ & $0.1-0.2$ \\
\hline
\end{tabular}

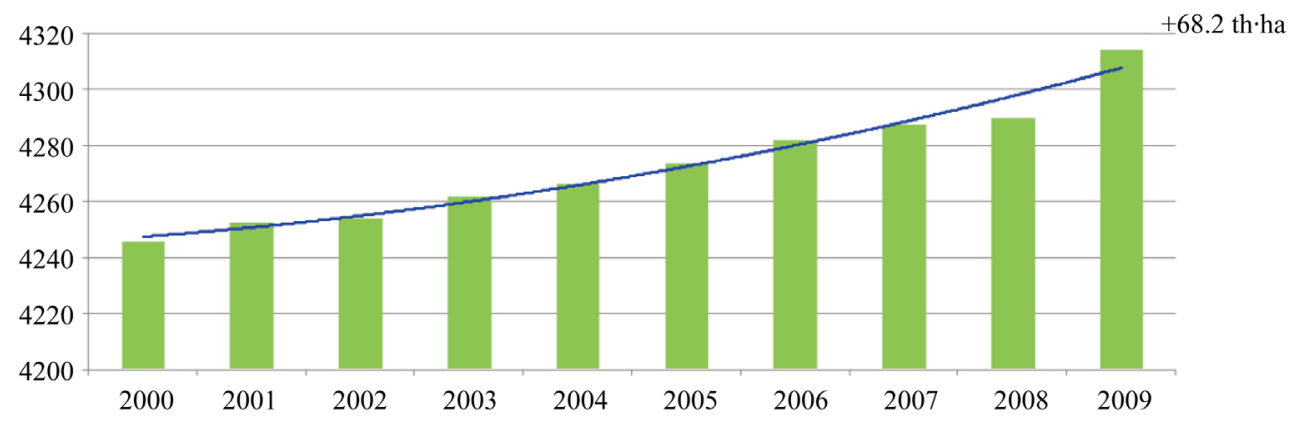

Figure 6. Dynamic of change the total area of the irrigated lands, th·ha. 
reasons for the high level of groundwater table on saline soils is the constant pressure-rising flow of deep groundwater.

The quantity of infiltration water depends on the quantity of vegetation irrigation, irrigation and watering norm, the nature, severity and frequency of the precipitation (rain, snow), and water-physical properties (water permeability) of soil and lands of the aeration zone. As seen above, groundwater level in during one year may trend to be large variations in this regard, the area of irrigated lands within the category of groundwater may also increase and decrease. For example, the area of groundwater to $1.0 \mathrm{~m}$ was 102.1 th.ha in 2007 and 49.4 th.ha in 2008, which is almost 2 times less than in 2007 (Figure 7).

The data presented in Figure 7 shows that the level of groundwater in the irrigation zone of Uzbekistan varies widely from 0.5 - 1.0 to 5 - 10 meters or more from their area change over the years. In 2009, compared to 2008, the area of irrigated land in the zone of groundwater to 1.0 $\mathrm{m}$ increased to 68.4 ha, or 1.38 times. The largest area of the zone of groundwater at a depth of $1 \mathrm{~m}$ accounted for in 2003. Then, the area was 181.8 th.ha, or $4.26 \%$ of the irrigated land. In 2007, the area of groundwater from 1.0 to $1.5 \mathrm{~m}$ was $313.3 \mathrm{th} \cdot \mathrm{ha}$, and $229.7 \mathrm{~m}$ tha in 2008 of irrigated land, or 1.36 times less than in 2007. In 2009, compared to 2008, the area of irrigated land located in the area of groundwater table increased to 259.3 th.ha, or $12.9 \%$. The largest area of the zone of groundwater table at a depth of 1.0 to 1.5 meters came in 2003, while in the area was 450.5 th·ha or $10.6 \%$ of irrigated area (Figure 7 ). The largest area of the zone of groundwater at a depth of 1.5 to $2.0 \mathrm{~m}$ accounted for 2007 - 1035.1 th $\cdot$ ha or $24.14 \%$ of irrigated land, and in 2009, compared to 2007, located in the area of their the zone of groundwater decreased to 766.1 th.ha, or $35.1 \%$. The largest area of the zone of groundwater at a depth of 2.0 to $3.0 \mathrm{~m}$ occurring in 2009 1709.9 th ha or $39.6 \%$ of irrigated land, and in 2009 , compared with 2007 , increased by their area to $16 \%$. The largest area of the zone of groundwater at a depth of 3.0 to $5.0 \mathrm{~m}$ accounted for 2002 is 794.9 th ha or $18.7 \%$ of the irrigated land. In 2009, compared to 2002, the area of irrigated lands is located in the area of groundwater table decreased to 737.6 th $\cdot$ ha or $7.76 \%$. The largest area of the zone of groundwater at a depth of $5.0 \mathrm{~m}$ accounted for 2001 is 783.3 th.ha or $18.41 \%$ of irrigated land, and in 2009, compared with 2001, its area was reduced to 760.1 ha or $3.05 \%$.

Groundwater table is often dependent on the drainagebasin relief. In river valleys, gullies, ravines and other depressions of relief groundwater are found at a relatively shallow depth. With the increase of the relief, depth of groundwater increases: it can reach tens of meters in the watersheds, hills, and other heights. Therefore, the movement of groundwater, with few exceptions, is directed from the sublime to the depressions. Due to differences of geomorphic unit in Uzbekistan, absolute elevation surface, and diversity of lithology and hydrogeological conditions of irrigated lands groundwater table in the irrigated areas are very different.

\subsection{Indicators of Groundwater Salinity}

The main factors of determining changes in groundwater salinity in both quantitative and qualitative terms are the original chemical composition of the sources of groundwater feeding, properties of water-bearing horizons, and interaction with groundwater, the impact of organisms and the nature of the balance groundwater. Groundwater salinity in the irrigated lands increases with the intensity of the flow of groundwater through evaporation and transpiration, and the closer the water table to the surface. In this context, the degree of groundwater mineralization has trends to increase or maintain reduction of salts, as shown in Figure 8. Maximum size of the area of groundwater with mineralization up to $1.0 \mathrm{~g} / \mathrm{l}$ occurred in 2009, while the area was 1612.3 th·ha or $37.37 \%$ of the irrigated lands,

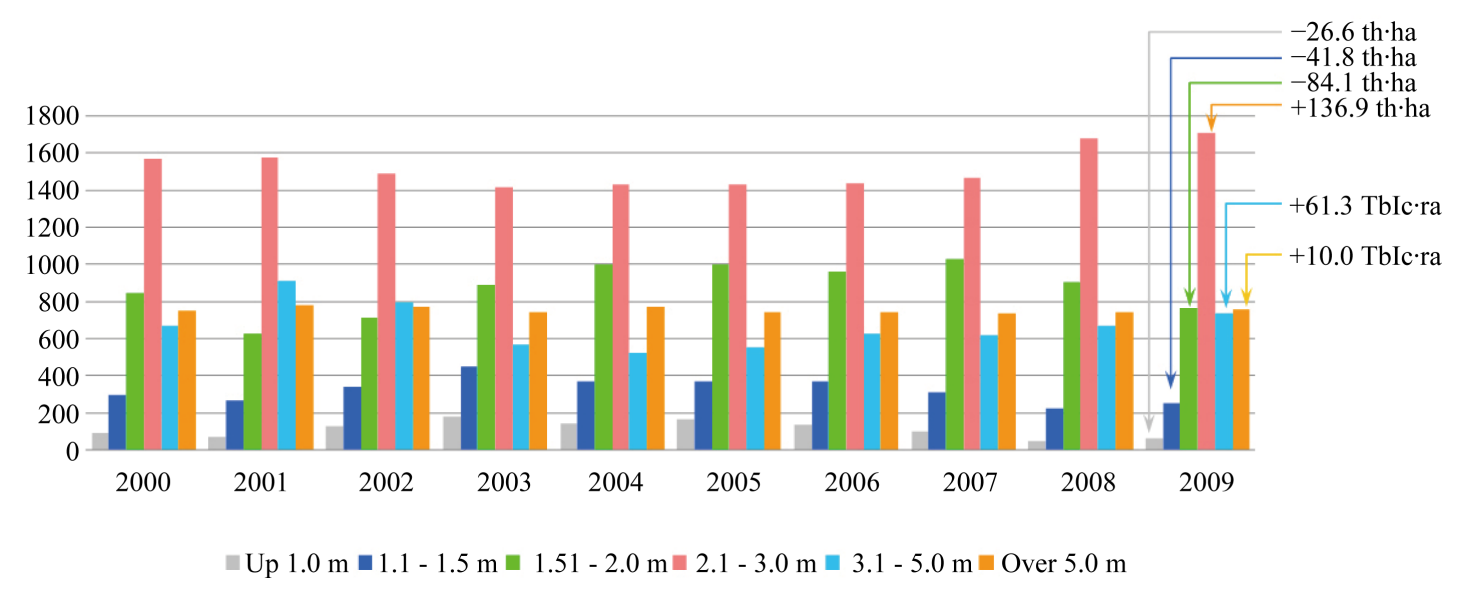

Figure 7. Dynamics of deposition groundwater table, th·ha. 


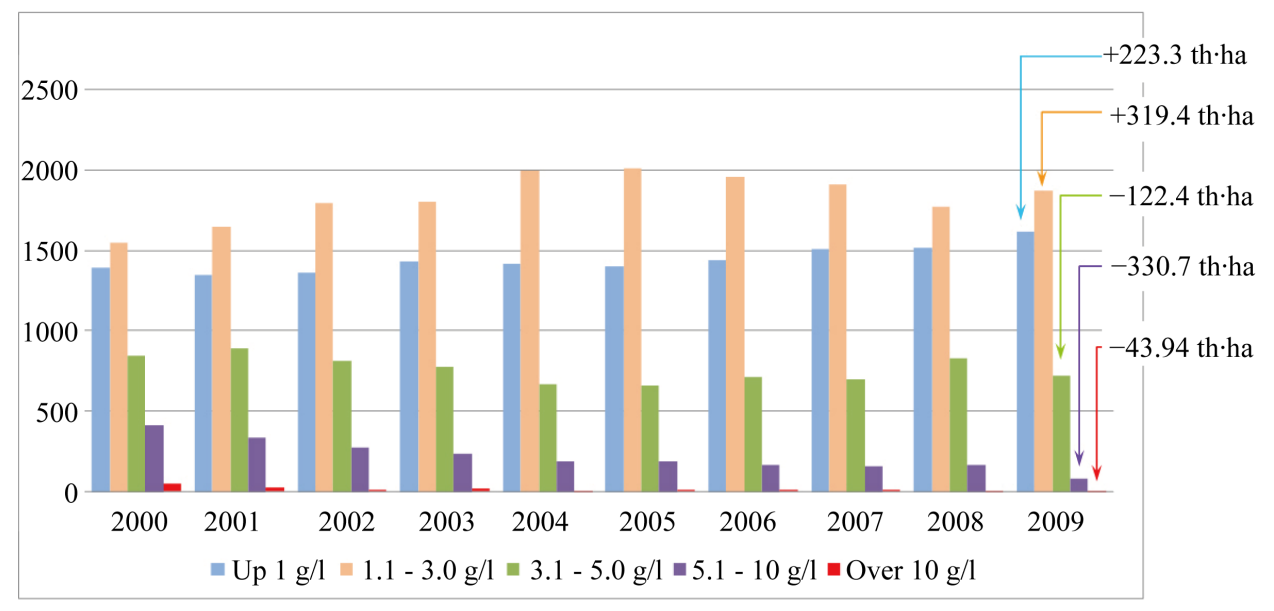

Figure 8. Dynamics of mineralization level of groundwater.

compared with 2000, where this area was 1,389.3 th.ha, or 16.05\% less than in 2009 (Figure 8).

In 2005, maximum size of the area of groundwater with a salinity of 1.1 to $3.0 \mathrm{~g} / \mathrm{l}$ is 2010.1 th ha or $47.03 \%$ of the irrigated lands, 1547.1 th.ha in 2000 or $36.43 \%$, and 1866.4 th ha or $43.26 \%$ of the irrigated lands in 2009 . Maximum size of the area of groundwater with a salinity of 3.1 to $5.0 \mathrm{~g} / \mathrm{l}$ accounted for 2001 in the amount of 892.1 th.ha or $20.97 \%$ of irrigated lands, and in 2005, the area of this zone was 664.0 th.ha, or $15.53 \%$, and in 2009, 721.3 th.ha, or $16.72 \%$ of the irrigated lands. Maximum size of the area of groundwater with salinity from 5.1 to $10.0 \mathrm{~g} / \mathrm{l}$ was 418.97 th $\cdot$ ha or $9.68 \%$ of the irrigated lands in 2000 , 167.6 th.ha or $3.9 \%$ in 2008 , and 88.3 th ha or $2.04 \%$ of the irrigated lands in 2009. Maximum size of the area of groundwater with salinity above $10.0 \mathrm{~g} / \mathrm{l}$ was $46.74 \mathrm{th} \cdot \mathrm{ha}$ or $1.1 \%$ of the irrigated lands in $2000,5.63$ th ha or $0.13 \%$ in 2008 , and 2.8 th.ha or $0.064 \%$ of all irrigated lands in 2009.

Movement of soluble salts mainly goes to low relief. In these areas, water-soluble salts accumulate and, in the long term, the conditions lead to the land unsuitable for growing crops.

\subsection{Salinization of Irrigated Lands}

Data on the performance of irrigated land salinity is shown in Figure 9. Out of 4313.9 th.ha or $50.2 \%$ of the irrigated lands in the Uzbekistan, the degree of salinity varies significantly, including 31.2\% - slightly, 15.30\% moderately and $3.27 \%$ - very saline lands.

The area of the irrigated lands belonging to a category not saline increased from 1944.6 th.ha to 2165.9 th.ha between 2000 and 2009 (Figure 9). Thus, the area of the irrigated lands of this category increased by 221.3 th·ha and that accounts for $50.2 \%$ of the total area of the irrigated lands. The area of the irrigated lands that could be regarded as slightly saline was increased from 1263.3 th·ha to 1347.6 th·ha between 2000 and 2009. Thus, the area of the irrigated lands in this category increased by 84.3 th.ha, and accounted for $31.23 \%$ of the total irrigated lands. The area of the irrigated lands, which is moderately saline decreased from 847.6 th.ha to 646.7 th.ha. Between 2000 and 2009, for a moderately saline lands decrease of 200.9 th ha or $14.9 \%$ of total irrigated lands. The area of the irrigated lands belonging to a category saline decreased from 190.1 th ha to 141.3 th.ha. Between 2000 and 2009, a net decrease of 48.8 th·ha or $3.27 \%$ of total irrigated lands (Figure 9).

\subsection{Ameliorative Conditions of the Irrigated Lands}

The data on ameliorative conditions of the irrigated lands is shown in Figure 10. The area of the irrigated lands in a good ameliorative condition increased from 1615.1 th·ha in 2000 to 1839.0 th·ha in 2009 (Figure 10). Thus, the area of the irrigated lands in this category increased by 223.9 th.ha and constitutes $42.6 \%$ of the total area of the irrigated lands. The area of the irrigated lands in a satisfactory ameliorative condition decreased from 2290.9 th.ha to 2170.3 th.ha between 2000 and 2009. Lands of this category constitute $50.3 \%$ of the area of the irrigated lands (Figure 9). The areas of the irrigated lands which are on category of unsatisfactory ameliorative condition decreased from 339.6 th.ha to 304.6 th.ha. Between 2000 and 2009, the area of the irrigated lands of this category decreased by 35.0 th.ha. From the total area of the irrigated lands available in the country in 2009, 7.06\% was in unsatisfactory ameliorative condition. Thus, the analysis of data given in Figure 10 shows the following trends. Some improvement of ameliorative condition of the irrigation lands was noted. There was also a significant reduction in the percentage of the irrigated lands in the satisfactory conditions between 2000 and 2009 (-120.6 th.ha). There was an insignificant reduction in the pro- 


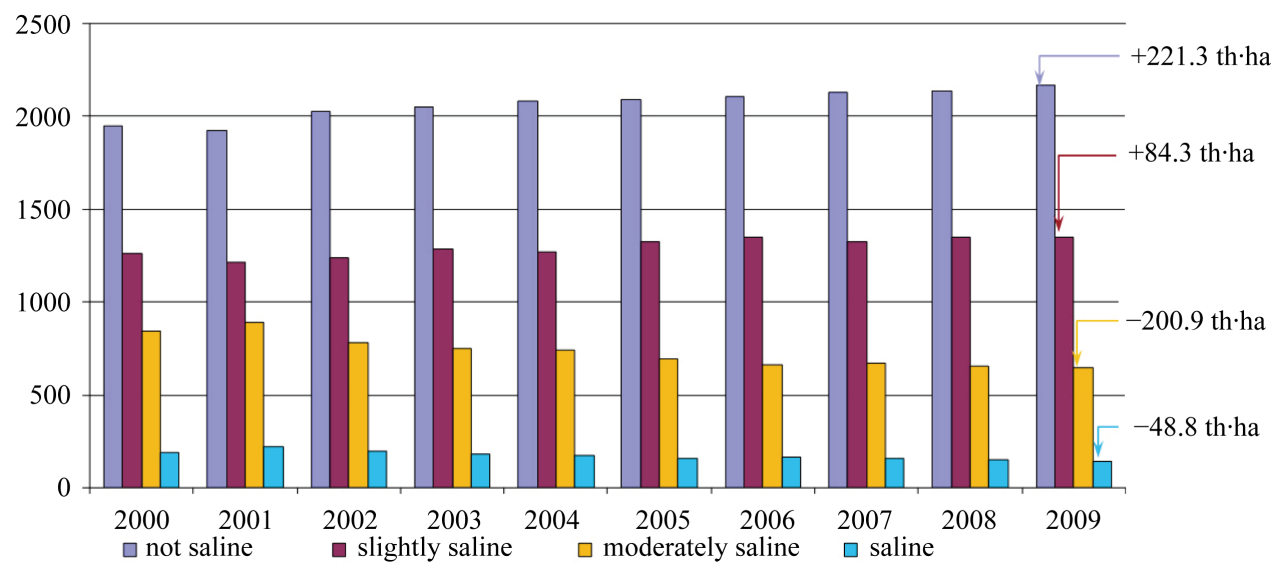

Figure 9. Dynamics of salinization degree of the irrigated lands.

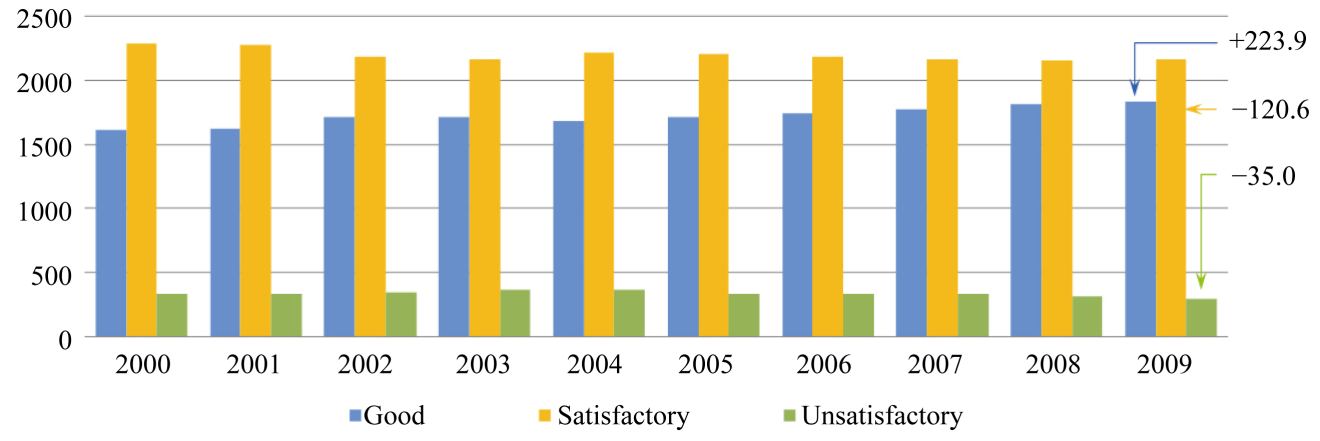

Figure 10. Ameliorative conditions of the irrigated lands, th.ha.

portion of the lands in unsatisfactory ameliorative condition between 2000 and 2009 ( -35 th.ha). In general, some increase of quantity of the irrigated lands having a good ameliorative condition is observed. Distribution of difficultly reclaimed irrigated lands across the regions has been investigated and the results are shown in Table 3 .

From the data shown in Table 3, it can be noted that the greatest area of difficultly reclaimed lands belongs to Karakalpakstan (26.2\%), Djizak (12.5\%) and Khorezm and Fergana regions (10.2\% - 10.5\%). In fact, Karakalpakstan is directly located in the zone of the Aral Sea disaster and influence of the drying up sea is visible. In these regions, it is recommended to lower level of groundwater table and carry out necessary ameliorative works. Favorable ameliorative conditions of the irrigated lands can be seen for Tashkent (3.6\%), Samarkand (5.4\%) and Syrdarya (5.7\%) regions. The territory of these regions is geographically located above sea level and groundwater table is found comparatively lower.

\section{Conclusions}

From our study, the following conclusions can be drawn:

1) Uzbekistan is using more than $50 \%$ of water resources of the region, and therefore, it is more vulnerable to the problems of water deficiency and pollution caused by mismanagement, use of outdated technologies, unsustainable agricultural practices and climate change impact. Therefore, the advancement and development of economic mechanisms in the sphere of water distribution and use at national and regional levels are needed.

2) Sustainable use and management of water and irrigated lands in Uzbekistan are essential for securing food production in light of climate change, decreasing water resources and growing population and economy, especially given the limited irrigated lands. Extensive flood irrigation with poor quality water and inefficient drainage facilities have accelerated soil degradation and salinization of irrigated lands of the country.

3) Fundamental problems of rational use of water resources in the agricultural sector must be addressed by: i) planning irrigated lands; ii) developing and improving scientifically-proved practices of crop irrigation; iii) water accounting; iv) developing advanced irrigation technologies; v) improving the mechanisms of accountability of water users; vi) increasing the efficiency of irrigation systems; vii) reducing organizational water losses; viii) increasing the efficiency of water use and reducing soil salinization.

4) The present state of the irrigated lands is characterized by insignificant improvement of ameliorative con- 
Table 3. Distribution of the area of difficultly of reclaimed irrigated lands across the regions of the country.

\begin{tabular}{ccccc}
\hline No. & The name of regions & Total of irrigated lands, th·ha & $\begin{array}{c}\text { Including difficultly reclaimed } \\
\text { lands, th·ha. }\end{array}$ & $\begin{array}{c}\text { Percentage from the total } \\
\text { irrigated lands }\end{array}$ \\
\hline 1 & Karakalpakstan & 515.3 & 134.9 & 26.2 \\
2 & Andijan & 273.5 & 18.6 & 6.8 \\
3 & Bukhara & 275.1 & 19.9 & 7.2 \\
4 & Djizak & 301.2 & 37.4 & 12.5 \\
5 & Kashkadarya & 515.7 & 38.7 & 7.5 \\
6 & Navoi & 123.4 & 10.5 & 8.5 \\
7 & Namangan & 282.5 & 16.8 & 5.9 \\
8 & Samarkand & 379.2 & 20.6 & 5.4 \\
9 & Surkhandarya & 325.8 & 19.6 & 6.0 \\
10 & Syrdarya & 286.9 & 16.7 & 5.7 \\
11 & Tashkent & 396.8 & 14.3 & 3.6 \\
12 & Fergana & 366.2 & 38.5 & 10.5 \\
\end{tabular}

ditions. The measures on the improvement of ameliorative conditions of the irrigated lands in the country should include: i) decrease in salinization level of the irrigated lands; ii) reduction of groundwater table depth; iii) decrease in groundwater mineralization levels; iv) improving ameliorative conditions of irrigated lands.

5) Further expansion of irrigated lands is possible only with the improved irrigation technology: radical improvement and amelioration of old abandoned lands (for 25 - 30 years) by taking into account the limitation of natural resources, climate change, population growth, traditions, and local conditions, development of scientific potential and globalization factors.

\section{Acknowledgements}

The author is grateful to the Japan Society for the Promotion of Science (JSPS) for the Invitation Fellowship for Research in Japan under which the present work is carried out.

\section{REFERENCES}

[1] V. Dukhovny, "ICWC-Achievements and Challenges of the Future: Water Cooperation on the Way to Sustainable Development,” ICWC Tashkent, Tashkent, 2007.

[2] B. B. Alihanov, “About a Condition of Environment and Use of Natural Resources in Republic of Uzbekistan (the Retrospective Analysis for 1988-2007), National Report of the State Committee for Nature Protection of the Republic of Uzbekistan,” Chinor ENK, Tashkent, 2008.

[3] "The Reports of the State Department of Statistics of
Uzbekistan,” Tashkent, 2012. www.statistics.uz.

[4] V. Dukhovny and J. L. G. de Schutter, "Water in Central Asia-Past, Present, Future,” CRC Press, New York, 2011.

[5] R. Kulmatov, "Modern Problems in Using, Protecting and Managing Water and Land Resources of the Aral Sea Basin,” In: J. Qi and K. T. Evered, Eds., Environmental Problems of Central Asia and Their Economic, Social and Security Impacts, Springer, Dordrecht, 2008, pp. 2432. http://dx.doi.org/10.1007/978-1-4020-8960-2 2

[6] Asian Development Bank (EDS), "Research Prospectus: A Vision for Sustainable Land Management Research in Central Asia. Multi-Country Partnership Framework Support Project on Sustainable Land Management Research,” ICARDA-Program Facilitation Unit, Tashkent, 2008.

[7] B. Qushimov, I. M. Ganiev, I. Rustamova, B. Haitov and K. R. Islam, "Land Degradation by Agricultural Activities in Central Asia,” In: R. Lal, M. Suleymenov, B. A. Stewart, D. O. Hansen and P. Doraiswamy, Eds., Climate Change and Terrestrial Carbon Sequestration in Central Asia, Taylor \& Francis, London, 2007, pp. 137-147. http://dx.doi.org/10.1201/9780203932698.ch10

[8] V. Chub and T. Osokova, "Second National Report of the Republic of Uzbekistan on UN FCCC,” Tashkent, 2008.

[9] MAWR-Ministry of Agricultures and Water Resources (EDS), “Annual Reports 2000-2010,” Internal Document, Tashkent, 2011, 375 p,

[10] SCLGC-State Committee of the Republic of Uzbekistan on Land Resources geodesy, cartography and state cadaster (EDS), “Annual Reports 2000-2010,” Internal Document, Tashkent, 2012, 218 p.

[11] V. Priklonskiy, "The Methodical Recommendations on Mineralization of Solonetz Lands and Accounting Saline Soils,” Kolos, Moscow, 1970. 